\title{
Catalytic Aerobic Oxidation of Lignocellulose Derived Levulinic Acid in Aqueous Solution: A Novel Route to Synthesize Dicarboxylic Acids for Bio-based Polymers
}

Lei Song, ${ }^{[a], ~[b] ~ R u i ~ W a n g, ~}{ }^{[c]}$ Li Che, ${ }^{[a]}$ Yu Jiang, ${ }^{[b]}$ Mo Zhou, ${ }^{[b]}$ Yu Zhao, ${ }^{[b]}$ Jifeng Pang, ${ }^{[b]}$ Min Jiang, ${ }^{[c]}$ Guangyuan Zhou, ${ }^{*}[\mathrm{c}]$ Mingyuan Zheng, ${ }^{*}[\mathrm{~b}],[\mathrm{d}]$ and Tao Zhang ${ }^{[\mathrm{b}],[\mathrm{e}]}$

[a] Environmental Science and Engineering, Dalian Maritime University, Dalian, 116026, China. Email: Liche@dlmu.edu.cn

[b] CAS Key Laboratory of Science and Technology on Applied Catalysis, Dalian Institute of Chemical Physics, Chinese Academy of Sciences, 116023, China. E-mail: myzheng@dicp.ac.cn

[c] Division of Energy materials, Dalian Institute of Chemical Physicals, Chinese Academy of Sciences, 116023, China. E-mail: gyzhou@dicp.ac.cn

[d] Dalian National Laboratory for Clean Energy, Dalian 116023, People's Republic of China

[e] State Key Laboratory of Catalysis, Dalian Institute of Chemical Physics, Chinese Academy of Sciences, 116023, China

\section{Methods}

Materials. All chemicals were obtained from commercial sources and used as received. $\mathrm{RuCl}_{3} \cdot 3 \mathrm{H}_{2} \mathrm{O}$, $\mathrm{Pd}\left(\mathrm{NO}_{3}\right)_{2}, \mathrm{H}_{2} \mathrm{PtCl}_{6} \cdot 6 \mathrm{H}_{2} \mathrm{O}, \mathrm{HAuCl}_{4}, \mathrm{AgNO}_{3}, \mathrm{Ni}\left(\mathrm{NO}_{3}\right)_{2} \cdot 6 \mathrm{H}_{2} \mathrm{O}, \mathrm{Cu}\left(\mathrm{NO}_{3}\right)_{2}$, calcium oxide were purchased from Tianjin Damao Chemical Reagent Corporation. Activated carbon (C) was purchased from Norit Corporation. HT (magnesium-aluminum hydrotalcite) was purchased from Tianjin Heowns Biochem Technologies Co. Ltd. $\mathrm{SiO}_{2}$ was purchased from Qingdao Ocean Chemical Special Silicone Co. Ltd. Standard sample of 2hydroxy-2-methylsuccinic acid (citramalic acid, CA) with 95\% purity was purchased from Sigma-Aldrich Corporation. CA used for polymerization was prepared following the LA conversion method reported herein, with $99 \%$ purity after separation from the reaction solution and purification. Levulinic acid (LA, $99 \%$ ), TS-1 (titanium silicalite-1) and all other chemicals were analytical reagents and purchased from Aladdin Industrial Corporation.

Catalysts preparation. 1RuOx/support catalysts were prepared by incipient wetness impregnation of commercial supports $\left(\mathrm{SiO}_{2}, \mathrm{Al}_{2} \mathrm{O}_{3}, \mathrm{H} \beta, \mathrm{ZnO}, \mathrm{C}, \mathrm{HT}, \mathrm{TiO}_{2}, \mathrm{TS}-1, \mathrm{CaO}\right)$ with aqueous solutions of $\mathrm{RuCl}_{3} \cdot 3 \mathrm{H}_{2} \mathrm{O}$. The theoretical contents of metals in these catalysts were controlled at $1 \%$ by metal weight (denoted as $1 \mathrm{RuOx} / \mathrm{support}$ ). The samples were dried at $60{ }^{\circ} \mathrm{C}$ for $6 \mathrm{~h}$ and then at $80{ }^{\circ} \mathrm{C}$ for $2 \mathrm{~h}$. The obtained powders were calcined at $450{ }^{\circ} \mathrm{C}$ for $4 \mathrm{~h}$ in $\mathrm{N}_{2}$ for the $\mathrm{C}$ supported catalysts or in air for other catalysts.

Calcium oxide supported RuOx, PdOx, PtOx, AuOx, AgOx, NiOx and $\mathrm{CuOx}$ catalysts were prepared by incipient wetness impregnation of commercial $\mathrm{CaO}$ with aqueous solutions of $\mathrm{RuCl}_{3} \cdot 3 \mathrm{H}_{2} \mathrm{O}, \mathrm{Pd}\left(\mathrm{NO}_{3}\right)_{2}$, $\mathrm{H}_{2} \mathrm{PtCl}_{6} \cdot 6 \mathrm{H}_{2} \mathrm{O}, \mathrm{HAuCl}_{4}, \mathrm{AgNO}_{3}, \mathrm{Ni}\left(\mathrm{NO}_{3}\right)_{2} \cdot 6 \mathrm{H}_{2} \mathrm{O}$, and $\mathrm{Cu}\left(\mathrm{NO}_{3}\right)_{2}$, respectively. The theoretical contents of noble metals in these catalysts were controlled at $1 \%$ by metal weight (denoted as $1 \mathrm{MOx} / \mathrm{CaO}$ ). The samples were dried at $60^{\circ} \mathrm{C}$ for $6 \mathrm{~h}$ and then at $80^{\circ} \mathrm{C}$ for $2 \mathrm{~h}$. The obtained powders were calcined in air at $450^{\circ} \mathrm{C}$ for $4 \mathrm{~h}$.

Catalytic conversion of LA. The catalytic conversion of levulinic acid was performed in a stainless-steel autoclave. In a typical experiment, $3 \mathrm{~mL}$ of $0.05 \mathrm{~mol} / \mathrm{L}$ levulinic acid, $50 \mathrm{mg}$ of catalyst, $100 \mathrm{mg}$ of $\mathrm{CaO}$ and $0.5 \mathrm{MPa} \mathrm{O}_{2}$ were filled to the reactor, which was put in an oil bath at target temperatures under magnetic stirring. The reaction time was recorded as soon as the reactor temperature reached the target value. After reaction, the liquid product was cooled to room temperature and filtered for analysis. 
Procedure of copolymerization. CA and succinic acid (total $0.1 \mathrm{~mol}), 1,4$-butanediol $(0.25 \mathrm{~mol})$ and tetrabutyl titanate $(0.5 \mathrm{mmol})$ were loaded into a $25 \mathrm{~mL}$ three-neck flask equipped with a mechanical agitator. The air in the reactor was evacuated and replaced with nitrogen. The esterification step was conducted under nitrogen flow at $160^{\circ} \mathrm{C}$ for $1 \mathrm{~h}$ and $180^{\circ} \mathrm{C}$ for $5 \mathrm{~h}$. Afterwards, the polycondensation step was conducted at $200^{\circ} \mathrm{C}$ for $3 \mathrm{~h}$ under the pressure below $100 \mathrm{~Pa}$. After cooling to room temperature, the resulted copolyester was obtained as white solid material without further purification.

Analytical methods. The products in the reaction were analyzed by using high-performance liquid chromatography (HPLC, Agilent 1200) equipped with a Rezex ROA-Orgenic Acid $\mathrm{H}^{+}$column and a differential refractive index detector system. Mobile phase is $5 \mathrm{mmol} / \mathrm{L} \mathrm{H}_{2} \mathrm{SO}_{4}$ water solution. External standard method was used for the quantification.

The reactant conversion was calculated by the following equation:

$$
\text { Conversion }(\%)=\frac{\text { moles of reactant converted }}{\text { moles of reactant in feed }} * 100 \%
$$

The product selectivity was calculated by the following equation:

$$
\text { Selectivity }(\%)=\frac{\text { moles of product formed }}{\text { theoretical moles of product in reactant conversion }} * 100 \%
$$

${ }^{1} \mathrm{HNMR}$ and ${ }^{13} \mathrm{CNMR}$ spectra were recorded on Bruker AVANCE III $400 \mathrm{MHz}$ spectrometer.

X-ray diffraction (XRD) patterns of catalysts were collected on a PW3040/60 X'Pert PRO (PANalytical) diffractometer equipped with a $\mathrm{Cu}$ Ka radiation source $(\mathrm{k}=0.15432 \mathrm{~nm})$, operated at $40 \mathrm{kV}$ and $40 \mathrm{~mA}$. Data were collected from 10 to $80^{\circ}$ at a scanning speed of $5^{\circ} / \mathrm{min}$.

Fourier transform infrared spectroscopy (FTIR) measurement was performed in a transmission mode, using a BRUKER Equinox 55 spectrometer at a resolution of $4 \mathrm{~cm}^{-1}$ in the $4000-400 \mathrm{~cm}^{-1}$ range.

Raman spectroscopy measurement was performed in Raman-AFM combined imaging analysis system using a NanoWizard Ultra Speed \& inVia Raman spectrometer at $532 \mathrm{~nm}$ laser confocal Raman scanning the $1800-100 \mathrm{~cm}^{-1}$ range.

Products identification: Products in the reaction solution were first treated by methanol derivatization and then identified by GC-MS analysis. In detail, the reaction solution was evaporated to remove water. Then methyl esterification of products was conducted in $10 \% \mathrm{H}_{2} \mathrm{SO}_{4}$-methanol solution at $45{ }^{\circ} \mathrm{C}$ for $24 \mathrm{~h}$. Dichloroethane and a saturated aqueous solution of sodium chloride were added, followed with separation of the dichloroethane phase and drying it with anhydrous sodium sulfate. After filtration, the products in the dichloroethane was analyzed by GC-MS equipped with a Varian CP-WAX58 (FFAP) CB capillary column. The MS operating conditions are as follows: ion source temperature, interface temperature, and quadrupole temperature were set at 230,250 , and $40^{\circ} \mathrm{C}$, respectively. The electron ionization mode was set at $70 \mathrm{eV}$ with a mass range of $\mathrm{m} / \mathrm{z} 29-450$. ChemStationTM software was used for data acquisition, and the identification of various compounds was performed using a NIST Mass Spectral Library software (NIST 08, Software Version: $2.0 \mathrm{f}$ ).

HPLC-MS analysis: The high-performance liquid chromatography (HPLC, Agilent 1200) was equipped with a Rezex ROA-Orgenic Acid $\mathrm{H}^{+}$column. The MS (Agilent $6540 \mathrm{Q}-\mathrm{TOF}$ ) was operated under following conditions: dual ESI: negative mode $\mathrm{m} / \mathrm{z} 20-1000$, gas temperature: $350^{\circ} \mathrm{C}$, drying gas: $8 \mathrm{~L} / \mathrm{min}$, nebulizer: 35 psig, voltage of capillary: $3500 \mathrm{~V}$.

lodine quantity method: The method was referred to a previous report. ${ }^{\mathrm{S}}$ In detail, for the step A, $0.2 \mathrm{~g}$ of sample and $40 \mathrm{~mL}$ of water were fed in a $100 \mathrm{~mL}$ erlenmeyer flask, and then $6 \mathrm{~mL}$ of $30 \%$ sodium hydroxide solution, $10 \mathrm{~mL}$ of $20 \%$ potassium iodide solution and $10 \mathrm{~mL}$ of $36.5 \%$ concentrated hydrochloric acid solution were added successively, followed with sufficient shaking until the solid sample was completely dissolved. After adding $0.05 \mathrm{~g}$ of starch to the as-prepared solution as the indicator (step B), the amount of iodine was titrated with $0.01 \mathrm{~mol} / \mathrm{L}$ sodium thiosulfate solution (Step C). According to the volume of the titrating solution used, the mass content of metal peroxide in the metal oxide was calculated. The measurement was conducted for three times, and the average value was adopted as the final result.

Gel permeation chromatography (GPC) was recorded on a Waters 1515 HPLC apparatus to test number-average molecular weight $\left(M_{n}\right)$, weight-average molecular weight $\left(M_{w}\right)$ and its distribution $(\boxplus)$. Hexafluoroisopropanol (HFIP) was used as eluent $\left(1.0 \mathrm{~mL} / \mathrm{min}, 35^{\circ} \mathrm{C}\right)$ to evaluate relative molecular weight of different polyesters, and polymethyl methacrylate (PMMA) was used to establish a calibration curve. 
Differential scanning calorimetry (DSC) measurement was conducted on a Mettler Instrument. Measurements were carried out under $\mathrm{N}_{2}$ atmosphere and about 5 to $10 \mathrm{mg}$ of each sample was used for testing the thermal performance. The specific testing parameters were as follows: heating scan was recorded from $-60^{\circ} \mathrm{C}$ to $180^{\circ} \mathrm{C}$ at $10^{\circ} \mathrm{C} / \mathrm{min}$ and hold at $180^{\circ} \mathrm{C}$ for 3 min to eliminate the thermal history, then the sample was cooled to $-60^{\circ} \mathrm{C}$ at $10^{\circ} \mathrm{C} / \mathrm{min}$, and then the second heating scan was recorded from $60^{\circ} \mathrm{C}$ to $180^{\circ} \mathrm{C}$ at $10^{\circ} \mathrm{C} / \mathrm{min}$. The relevant results were obtained from TA Universal Analysis.

Moisture permeance factors were measured by a permeation test system (W3/330, Labthink, Ji' nan, China) using the polyester films obtained from the melt-press procedures. The films (cut into circular discs with diameter around $5.0 \mathrm{~cm}$ ) were conducted at $23^{\circ} \mathrm{C}$ and $50 \%$ relative humidity $(\mathrm{RH})$.

Tensile strength testing. Each melt-pressed film was cut into strips $(50 \mathrm{~mm} \times 5.0 \mathrm{~mm} \times 0.2 \mathrm{~mm})$. The strength and strain of the specimens at the breaking point were measured by tensile strength tests on a universal material testing machine (EZ-test; Shimadzu) at $23^{\circ} \mathrm{C}$. The grip distance was $10 \mathrm{~mm}$, and the tensile strength test speed was $2 \mathrm{~mm} / \mathrm{min}$. The average value is taken over three samples measured under the same conditions.

Water contact angle test. The hydrophilicity of all the films was evaluated by contact angle measurements using a drop shape analysis system (German KRUSS video optical contact angle measuring instrument $)$ at room temperature through sessile droplet technique. DI water $(2 \mu \mathrm{L})$ was used to measure the contact angle of all the films.

High-angle annular dark-field scanning-transmission electron microscopy (HAADF-STEM) images and energy-dispersive X-ray spectroscopy (EDS) elemental mapping were obtained by using a JEM-2100F microscope, operated at a voltage of $200 \mathrm{kV}$.

X-ray photoelectron spectroscopic (XPS) data were obtained using a Thermo Scientific K-Alpha+ spectrometer with $\mathrm{Al} \mathrm{Ka}$ radiation as the excitation source. The binding energies were corrected by using the $\mathrm{C} 1 \mathrm{~s}$ peak at $284.4 \mathrm{eV}$ as reference.

\section{Reference:}

[S1] Wagner, C. D.; Smith, R. H.; Peters, E. D. Determination of Organic Peroxides: Evaluation of Modified lodometric Method. Anal. Chem. 1947, 19, 976-979. 

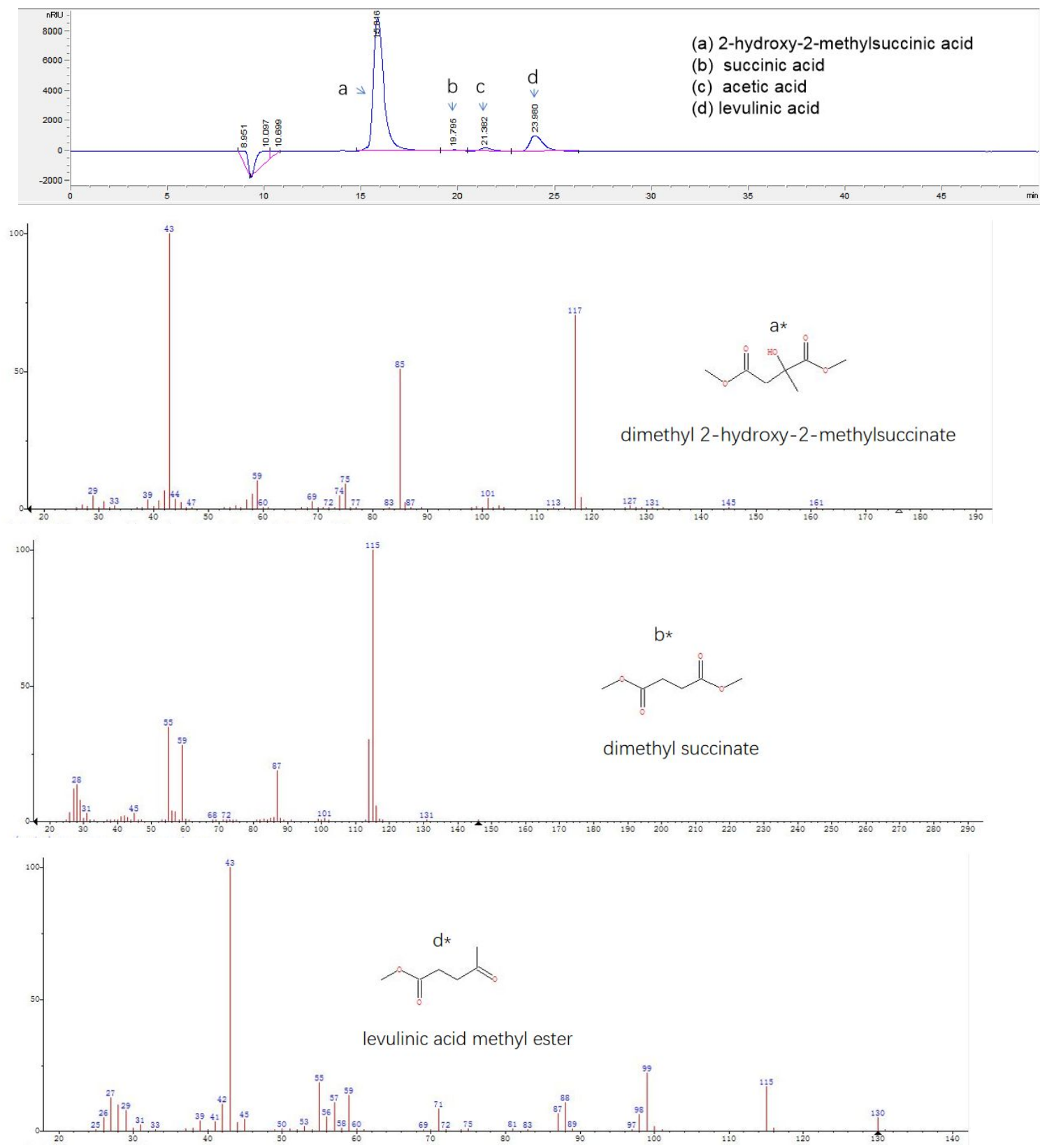

Figure S1. HPLC chromatogram and GC-MS spectra of products in LA conversion over the $1 \mathrm{RuOx} / \mathrm{CaO}$ catalyst. Products in the reaction solution were esterified with methanol, and identified by GC-MS. $a^{*}, b^{*}$ and $\mathrm{d}^{*}$ are the esterified products of 2-hydroxy-2-methylsuccinic acid (a), succinic acid (b), and levulinic acid (d), respectively. 


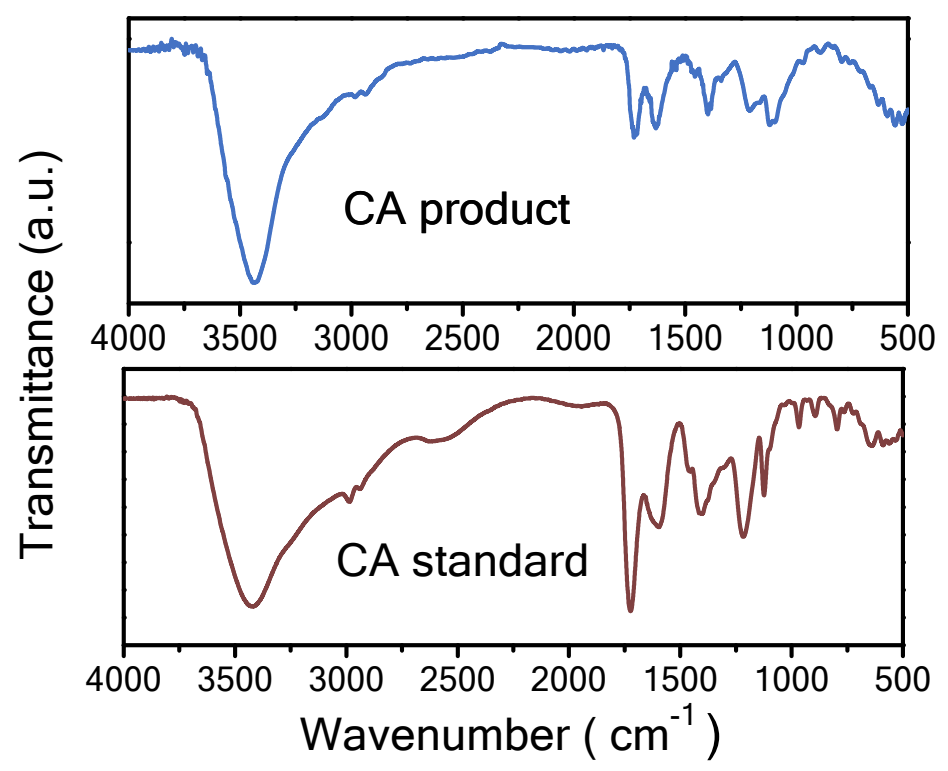

Figure S2. FTIR spectra of CA product obtained and standard CA sample.

As shown in the figure, the FTIR spectrum of CA product in our study is consistent to that of the standard sample.
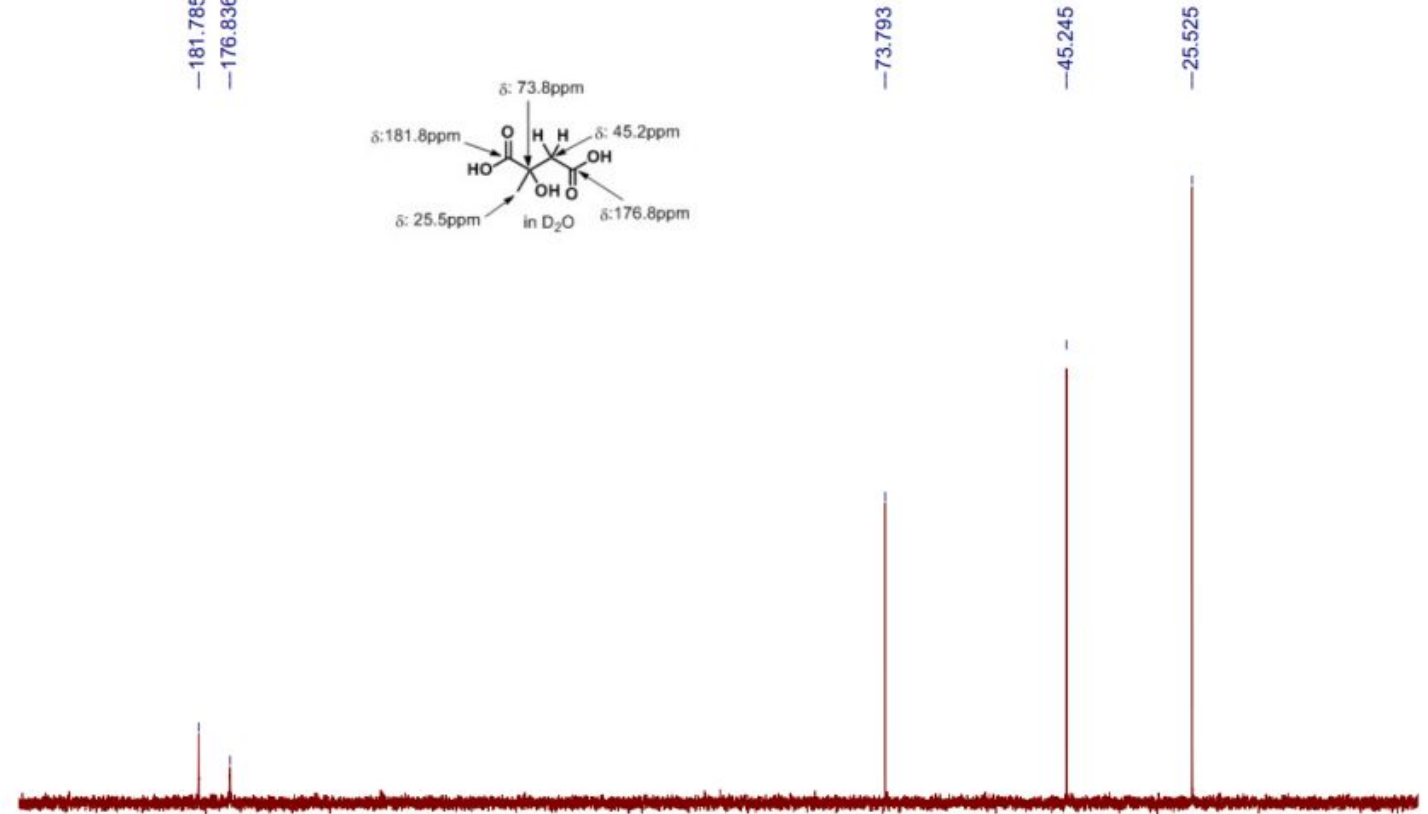

\begin{tabular}{llllllllllllllll}
\hline 10 & 190 & 170 & 150 & 130 & $110_{\mathrm{f} 1(\mathrm{ppm})} 90$ & 80 & 70 & 60 & 50 & 40 & 30 & 20 & 10 & 0 & -1
\end{tabular}

Figure S3. ${ }^{13} \mathrm{CNMR}\left(101 \mathrm{MHz}, \mathrm{D}_{2} \mathrm{O}\right)$ spectra of purified product CA. ${ }^{13} \mathrm{CNMR}\left(101 \mathrm{MHz}, \mathrm{D}_{2} \mathrm{O}\right.$ ) of purified product CA $\delta$ 181.785, 176.836, 73.793, 45.245, 25.525. 


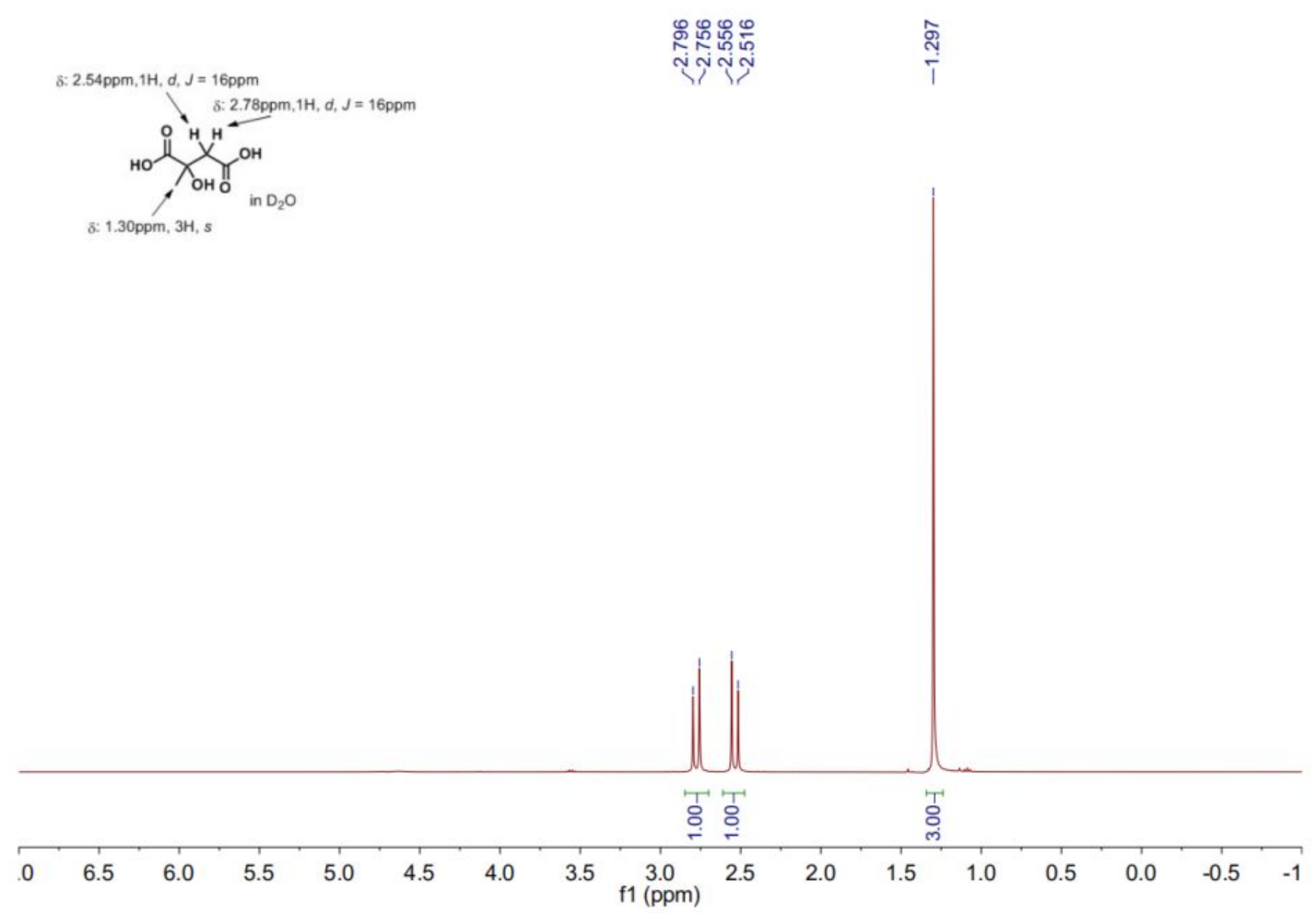

Figure S4. ${ }^{1} \mathrm{HNMR}\left(400 \mathrm{MHz}, \mathrm{D}_{2} \mathrm{O}\right)$ spectra of purified product $\mathrm{CA}$.

${ }^{1} \mathrm{HNMR}\left(400 \mathrm{MHz}, \mathrm{D}_{2} \mathrm{O}\right)$ of purified product CA $\delta 2.796,2.756,2.556,2.516,1.297$. 


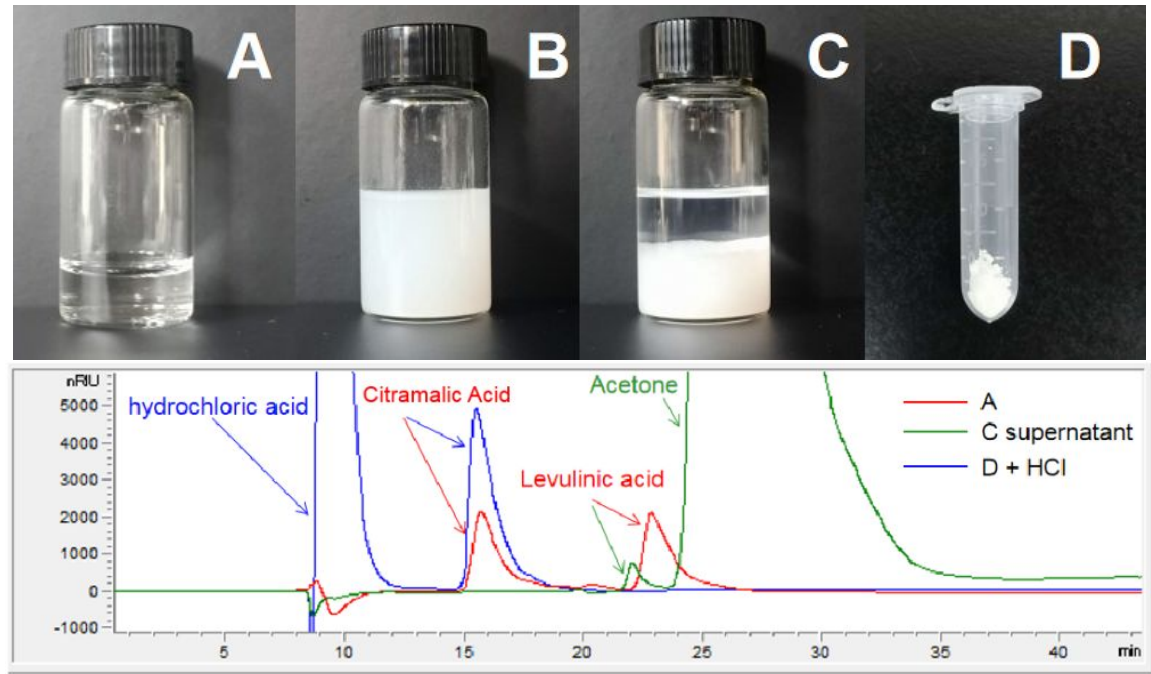

Figure S5. HPLC chromatograms of reactant solution (A, red line), supernatant of reactant solution after adding acetone ( $C$ supernatant, green line), and CA calcium salt dissolved in hydrochloric acid solution $(\mathrm{D}+\mathrm{HCl}$, blue line).

As shown in Figure S5, the reactant solution after reaction $(A)$ is clear, and the HPLC chromatogram (red line $A$ ) shows that CA product and levulinic acid were contained in the solution. After adding acetone to $A$, white precipitate was present (pictures B and C). HPLC analysis of the supernatant (green line C) shows that levulinic acid and acetone were retained in the solution but without CA in it. HPLC analysis of the precipitate after dissolving it in a $\mathrm{HCl}$ solution (blue line $\mathrm{D}$ ) shows that the precipitate should be $\mathrm{CA}$ calcium salt with a good purity. 


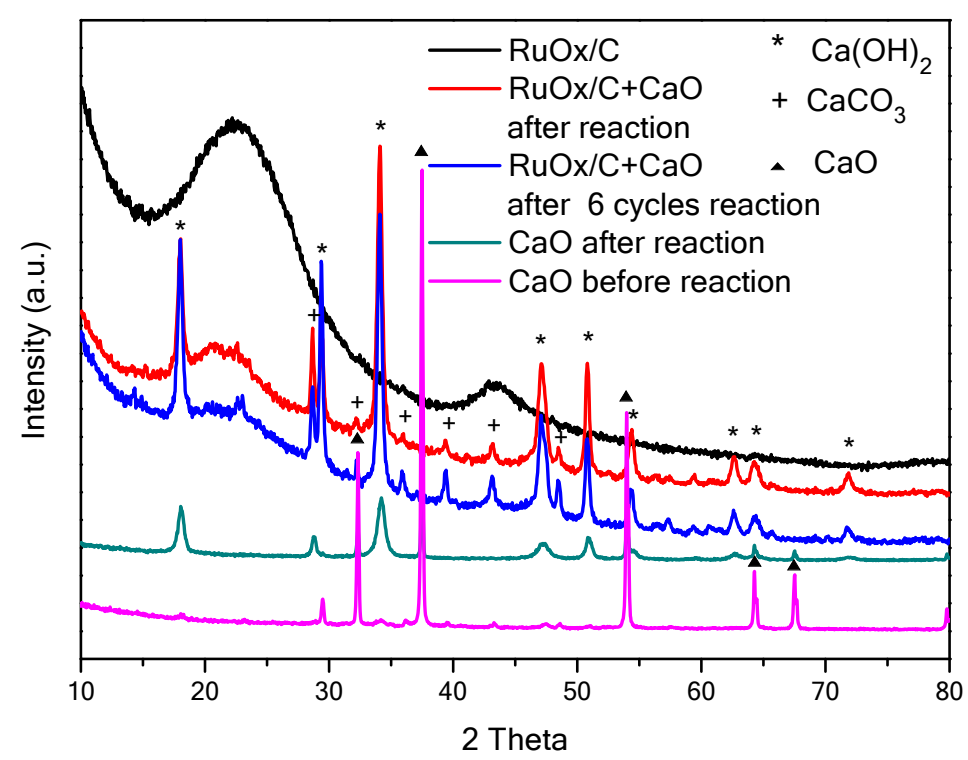

Figure S6. XRD patterns of the binary catalyst of $1 \mathrm{RuOx} / \mathrm{C}$ and $\mathrm{CaO}$ before and after reaction. 

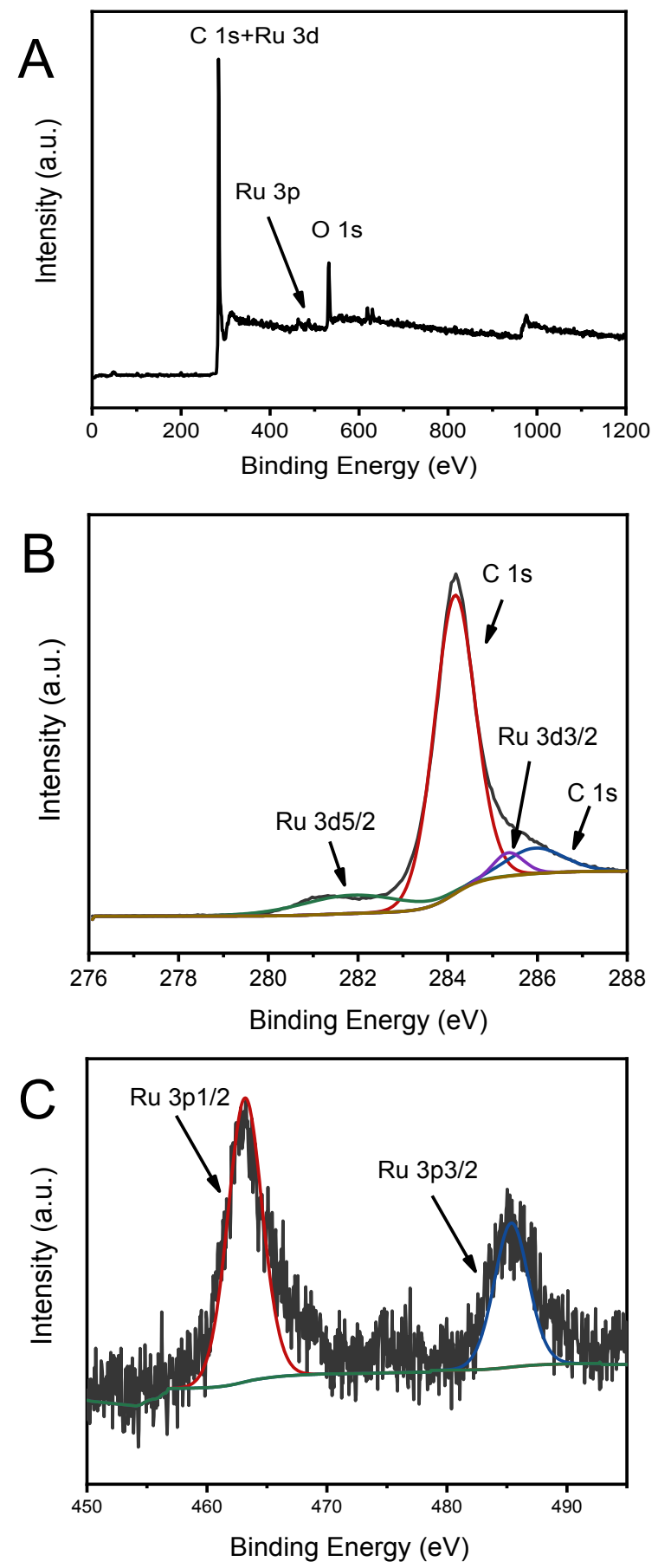

Figure S7. XPS spectra of RuOx/C catalyst. 

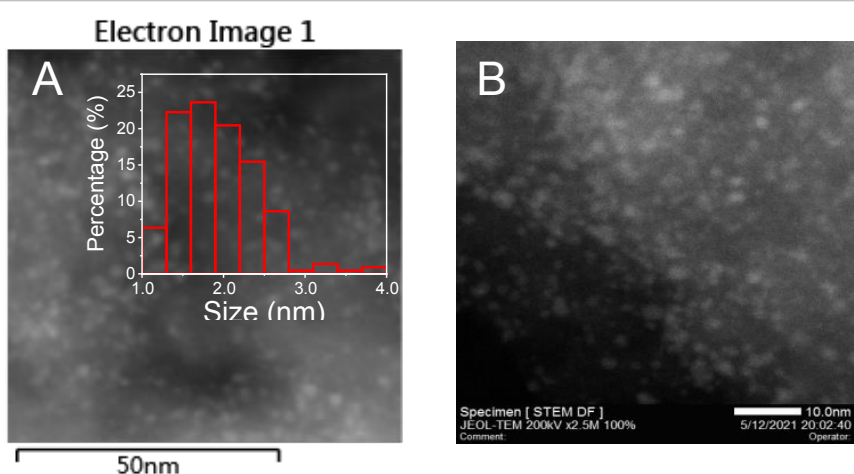

EDS Layered Image 1
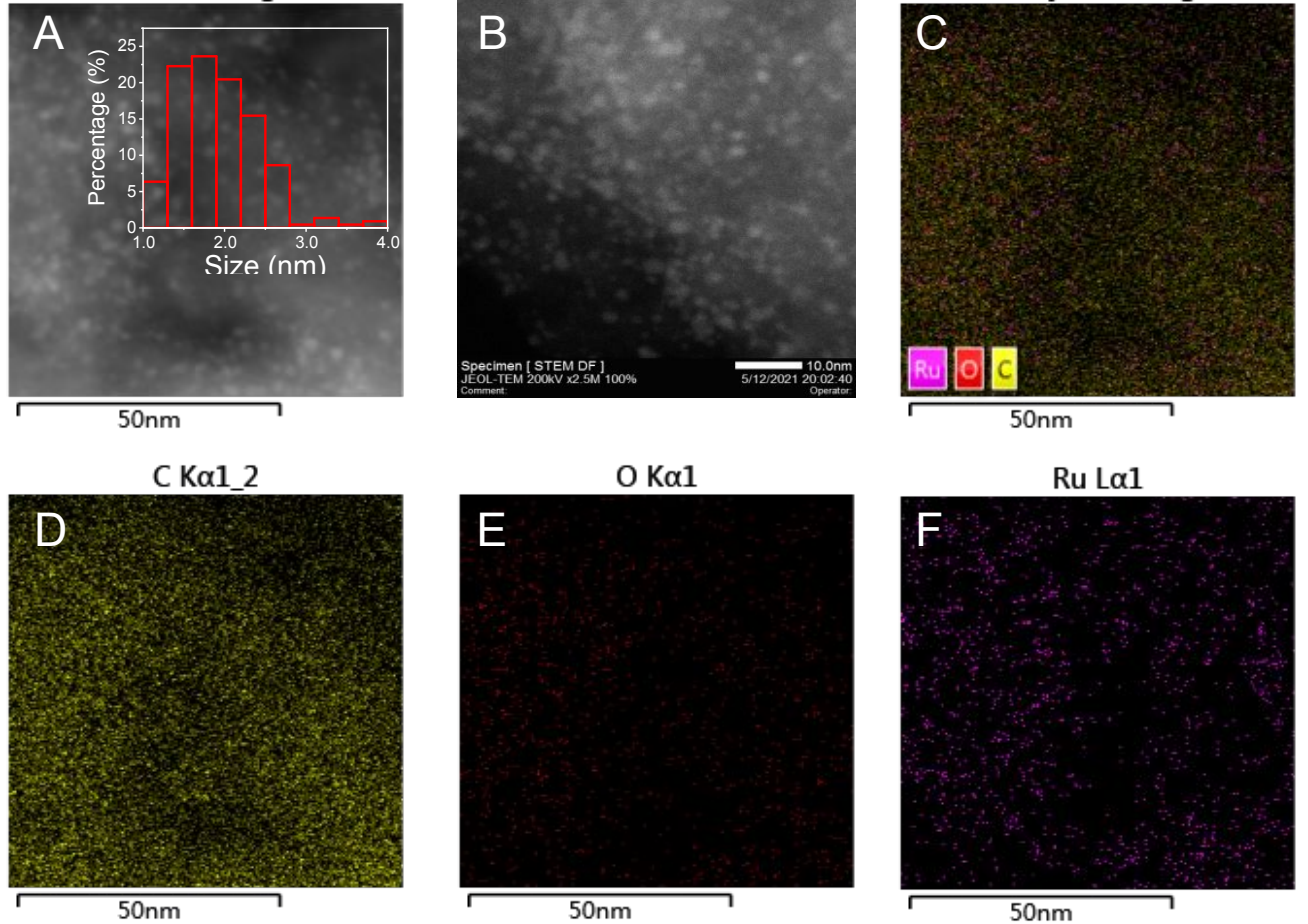

Figure S8. HAADF-STEM images (A, B) and EDS mapping (C-F) of 1RuOx/C catalyst. 

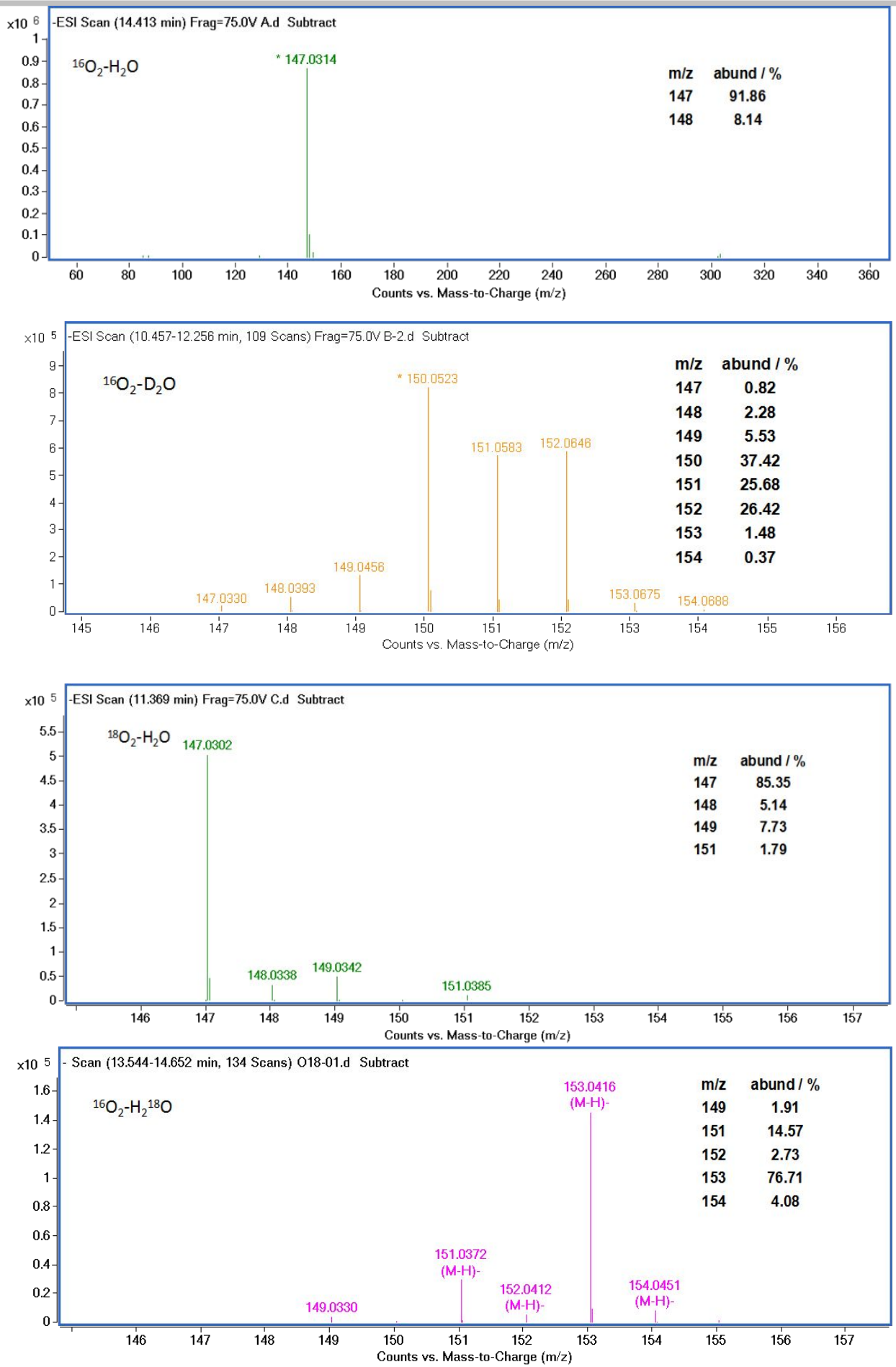

Figure S9. HPLC-MS spectra of CA products in ${ }^{16} \mathrm{O}_{2}-\mathrm{H}_{2} \mathrm{O},{ }^{16} \mathrm{O}_{2}-\mathrm{D}_{2} \mathrm{O},{ }^{18} \mathrm{O}_{2}-\mathrm{H}_{2} \mathrm{O}$ and ${ }^{16} \mathrm{O}_{2}-\mathrm{H}_{2}{ }^{18} \mathrm{O}$. 


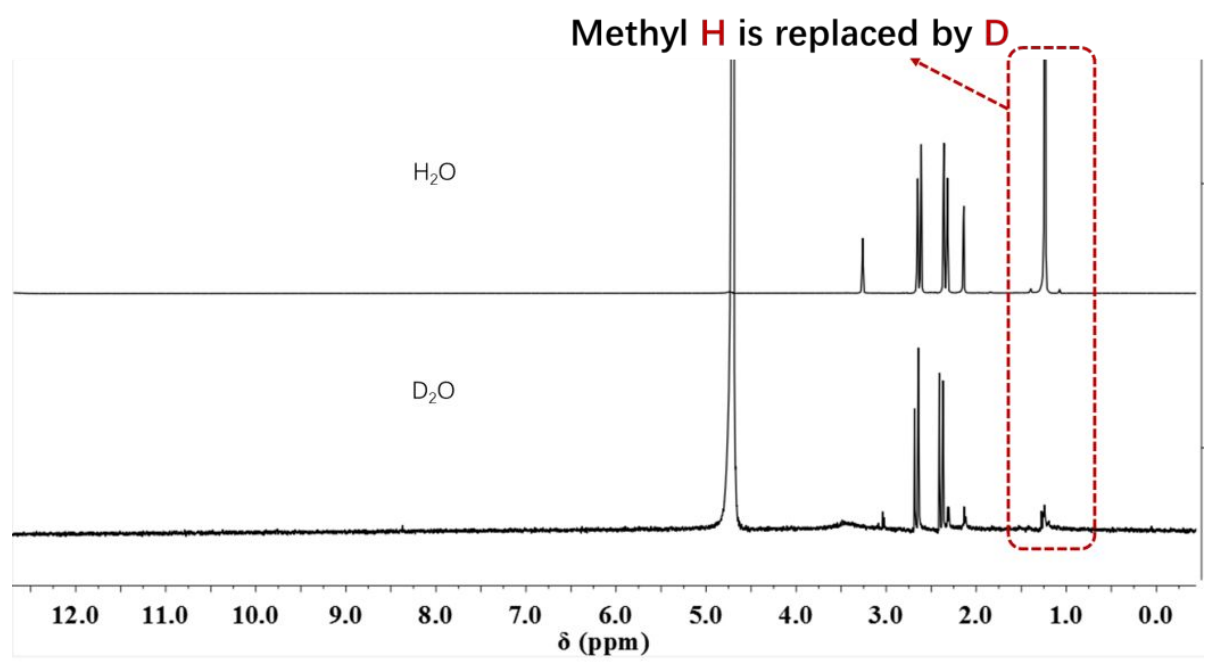

Figure S10. ${ }^{1} \mathrm{HNMR}\left(400 \mathrm{MHz}, \mathrm{D}_{2} \mathrm{O}\right)$ spectra of isolated calcium CA products in different solvents $\left(\mathrm{D}_{2} \mathrm{O}\right.$ and $\mathrm{H}_{2} \mathrm{O}$ ).

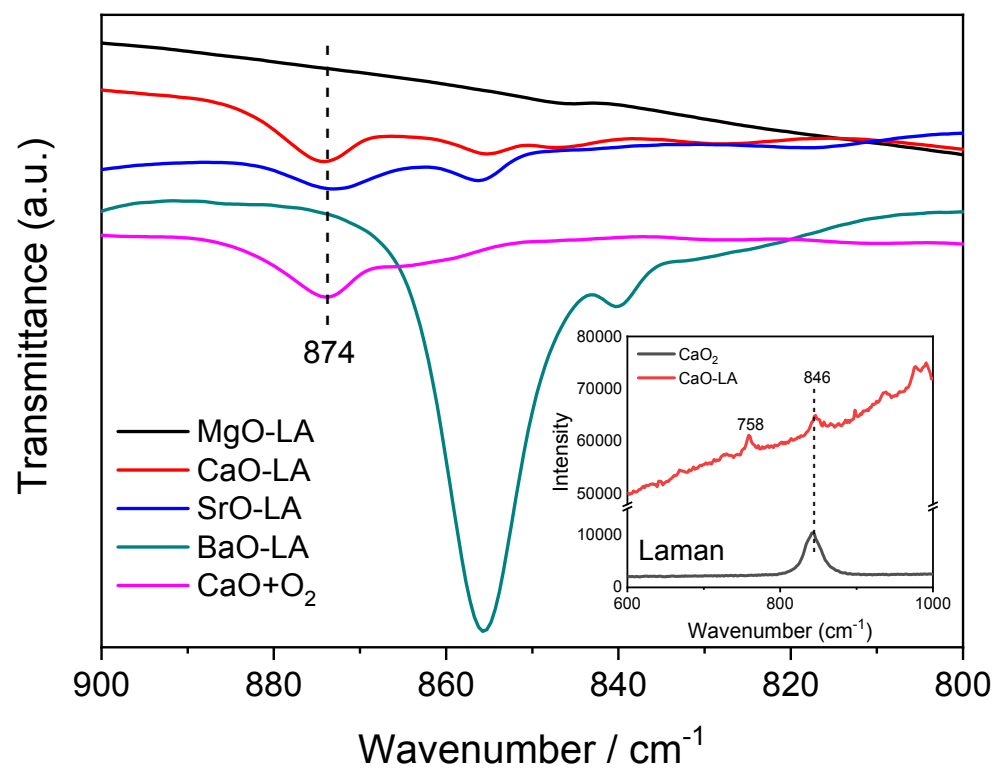

Figure S11. FTIR spectra of $\mathrm{MgO}, \mathrm{CaO}, \mathrm{SrO}$, and $\mathrm{BaO}$ after reaction, and Raman spectra of $\mathrm{CaO}$ after reaction and $\mathrm{CaO}_{2}$ sample (inset in the figure). Typical reaction conditions: $0.3 \mathrm{~g}$ of levulinic acid, $1 \mathrm{~mL}$ of water, $1.0 \mathrm{~g}$ of metal oxide, $70{ }^{\circ} \mathrm{C}, 1.0 \mathrm{MPa} \mathrm{O}_{2}, 0.5 \mathrm{~h}$, under magnetic stirring. The catalyst samples were dried at $60{ }^{\circ} \mathrm{C}$ before measuring the FTIR and Raman spectra. $\mathrm{CaO}+\mathrm{O}_{2}$ sample was obtained in the absence of levulinic acid under the same conditions to others. 


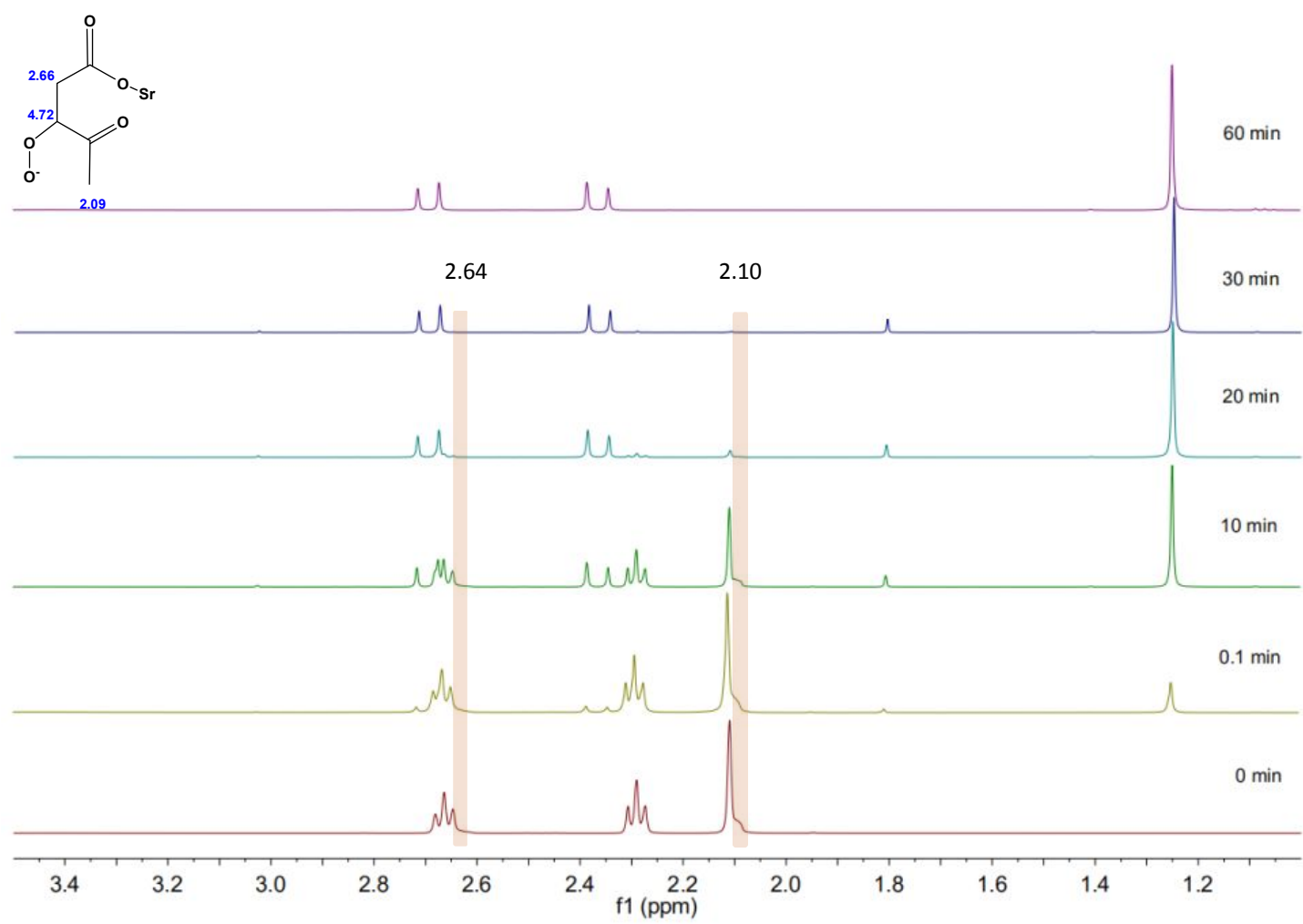

Figure S12. ${ }^{1} \mathrm{HNMR}\left(400 \mathrm{MHz}, \mathrm{D}_{2} \mathrm{O}\right)$ spectra of reactant solutions after treating at different times $(0-30$ $\mathrm{min}$ ). Typical reaction conditions: $3 \mathrm{~mL}$ of $0.05 \mathrm{~mol} / \mathrm{L}$ levulinic acid aqueous solution, under magnetic stirring, $50 \mathrm{mg}$ of $1 \mathrm{RuOx} / \mathrm{C}$ and $50 \mathrm{mg}$ of $\mathrm{SrO}, 90^{\circ} \mathrm{C}, 0.5 \mathrm{MPa} \mathrm{O}_{2}$. (Note: To increase the concentration of reaction intermediates, $\mathrm{SrO}$ was used instead of $\mathrm{CaO}$ in view of the superior catalytic performance of the former.)

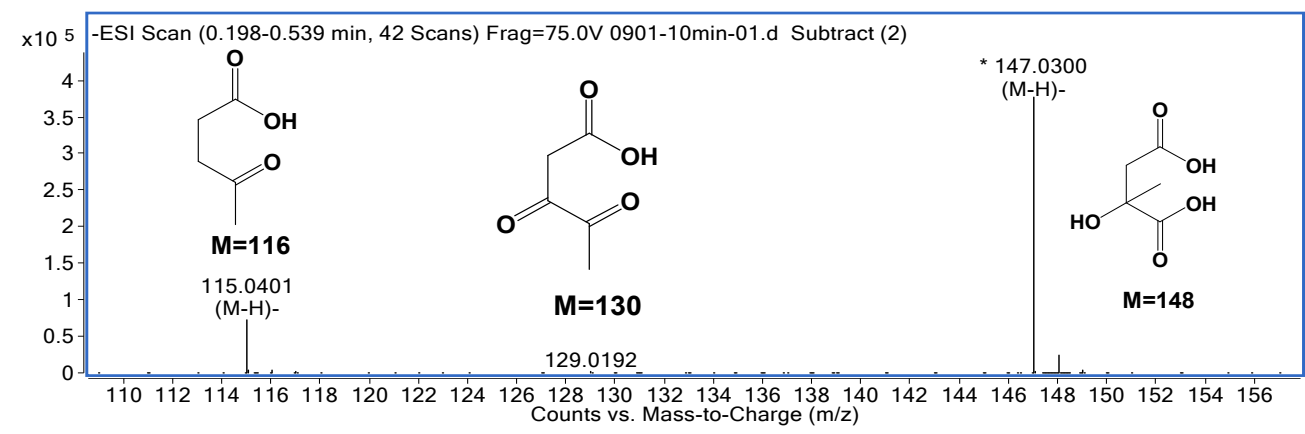

Figure S13. Mass spectroscopy analysis of reactant solution after 10 min reaction. Typical conditions: $3 \mathrm{~mL}$ of $0.05 \mathrm{~mol} / \mathrm{L}$ levulinic acid aqueous solution, under magnetic stirring, $50 \mathrm{mg}$ of $1 \mathrm{RuOx} / \mathrm{C}$ and $50 \mathrm{mg}$ of $\mathrm{CaO}$, $90{ }^{\circ} \mathrm{C}, 0.5 \mathrm{MPa} \mathrm{O}_{2}$. 


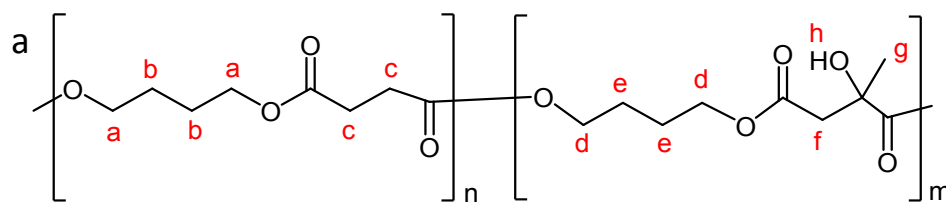

BS unit

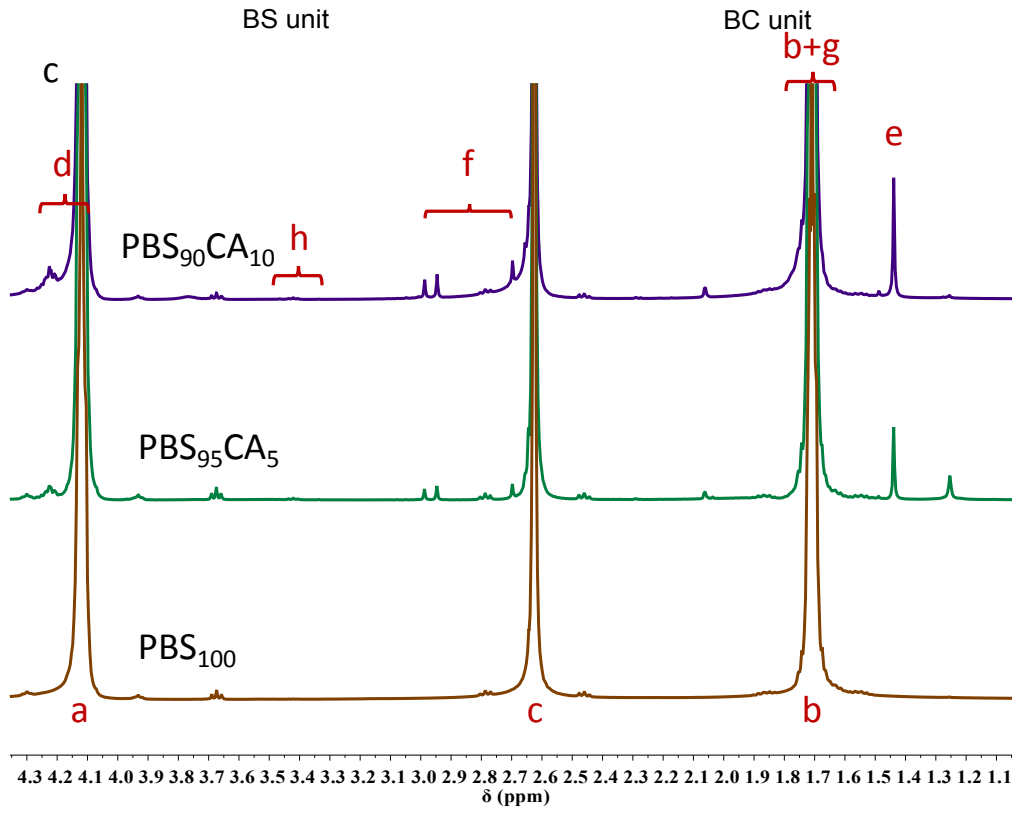<smiles>CC(=O)CCC(=O)OCCCC[Si]</smiles><smiles>CCCCOC(=O)CC(C)(O)C(=O)OCCCCCCC(C)=O</smiles><smiles>CC(=O)C(C)(O)CCCCCCCCCCOC(=O)CC(C)(O)C(C)=O</smiles>

d

Figure S14. (a) The structure of PBS-CAs, (b) Three triads in PBS-CAs, (c) ${ }^{1}$ HNMR spectra of PBS-CAs, (d) ${ }^{13} \mathrm{C}$ NMR of PBS-CAs.

The proton signals of the 1,4-BDO units appeared at a and d, indicating both CA and succinic acid (SA) form ester linkage with the diol. The proton signals of $H_{c}$ and $H_{f} / H_{g} / H_{h}$ are attributed to the SA and CA moieties of the copolyester PBS-CA, respectively. The compositions of the copolyesters can be calculated using Eqs. S1 and S2.

$$
\begin{gathered}
\left.\phi_{-}(\mathrm{CA})[\%]=I_{\mathrm{f}} / I_{\mathrm{f}}+I_{\mathrm{c}} / 2\right) \times 100 \% \\
\left.\phi_{-}(\mathrm{SA})[\%]=I_{\mathrm{c}} / 2 / \mathrm{f}+I_{\mathrm{c}} / 2\right) \times 100 \%
\end{gathered}
$$

where $I_{f}$ and $I_{c}$ denote the integral intensities of proton signals of $H_{f}$ for the CA moiety and $H_{c}$ for the SA moiety, respectively. The feed ratio of $\mathrm{CA}$ and $\mathrm{SA}$, as well as the composition ratio of butylene succinate (BS) and butylene citramalate (BC) units in the polymer are summarized in Table S7. Notably, the actual integration ratio of the signal of $-\mathrm{OH}$ group on the $\mathrm{CA}$ unit $\left(\mathrm{H}_{\mathrm{h}}, \delta 3.4-3.5 \mathrm{ppm}\right)$ is lower than the expected, suggesting that some of the $\mathrm{OH}$ - groups on $\mathrm{CA}$ units involved in the esterification reaction during the polymerization, leading to the formation of the slight cross-linking network in the copolyesters. 
d

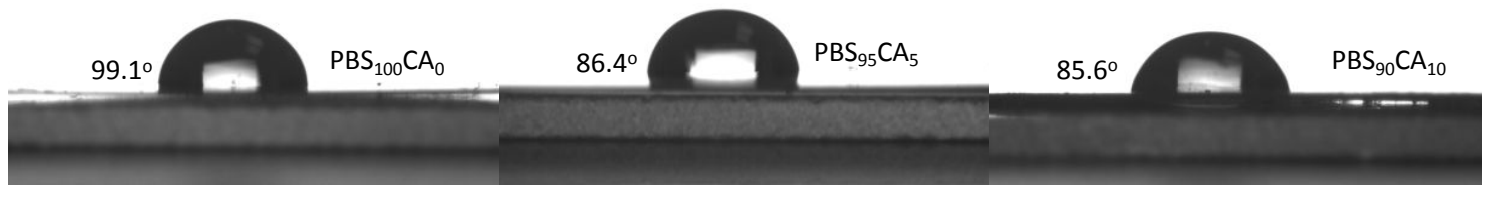

Figure S15. Water contact angle test of PBS-CAs with different composition ratios. 
Table S1. Results of $1 \mathrm{RuOx} / \mathrm{C}+\mathrm{CaO}$ reusability evaluation.

\begin{tabular}{|c|c|c|c|c|c|}
\hline \multirow{2}{*}{ Cycles } & \multirow{2}{*}{ Catalyst } & \multirow{2}{*}{$\begin{array}{c}\text { Conversion } \\
(\%)\end{array}$} & \multicolumn{3}{|c|}{ Selectivity (\%) } \\
\hline & & & $\mathrm{CA}$ & SA & $\mathrm{AA}$ \\
\hline 1 & & 90.8 & 94.7 & 0.8 & 2.5 \\
\hline 2 & & 84.5 & 96.3 & 0.4 & 2.6 \\
\hline 3 & & 77.9 & 96.0 & 0.4 & 2.1 \\
\hline 4 & $1 \mathrm{RuOx} / \mathrm{C}+\mathrm{CaO}$ & 74.2 & 96.1 & 0.6 & 2.3 \\
\hline 5 & & 72.4 & 93.0 & 0.5 & 1.6 \\
\hline 6 & & 71.7 & 90.2 & 1.7 & 2.5 \\
\hline
\end{tabular}

Reaction conditions: $1 \mathrm{RuOx} / \mathrm{C} 50 \mathrm{mg}$, $\mathrm{CaO} 100 \mathrm{mg}, 3 \mathrm{~mL}$ of $0.05 \mathrm{~mol} / \mathrm{L}$ levulinic acid aqueous solution, $0.5 \mathrm{MPa} \mathrm{O}_{2}, 90{ }^{\circ} \mathrm{C}, 0.5 \mathrm{~h}$; The catalyst is recovered by centrifugation after each reaction, and $25 \mathrm{mg}$ of $\mathrm{CaO}$ was added to the last recovered catalyst before each reaction. CA (2-hydroxy-2-methylsuccinic acid), SA (succinic acid), AA (acetic acid).

Table S2. Results of aerobic oxidation of LA and its homologs over $1 \mathrm{NiOx} / \mathrm{CaO}$.

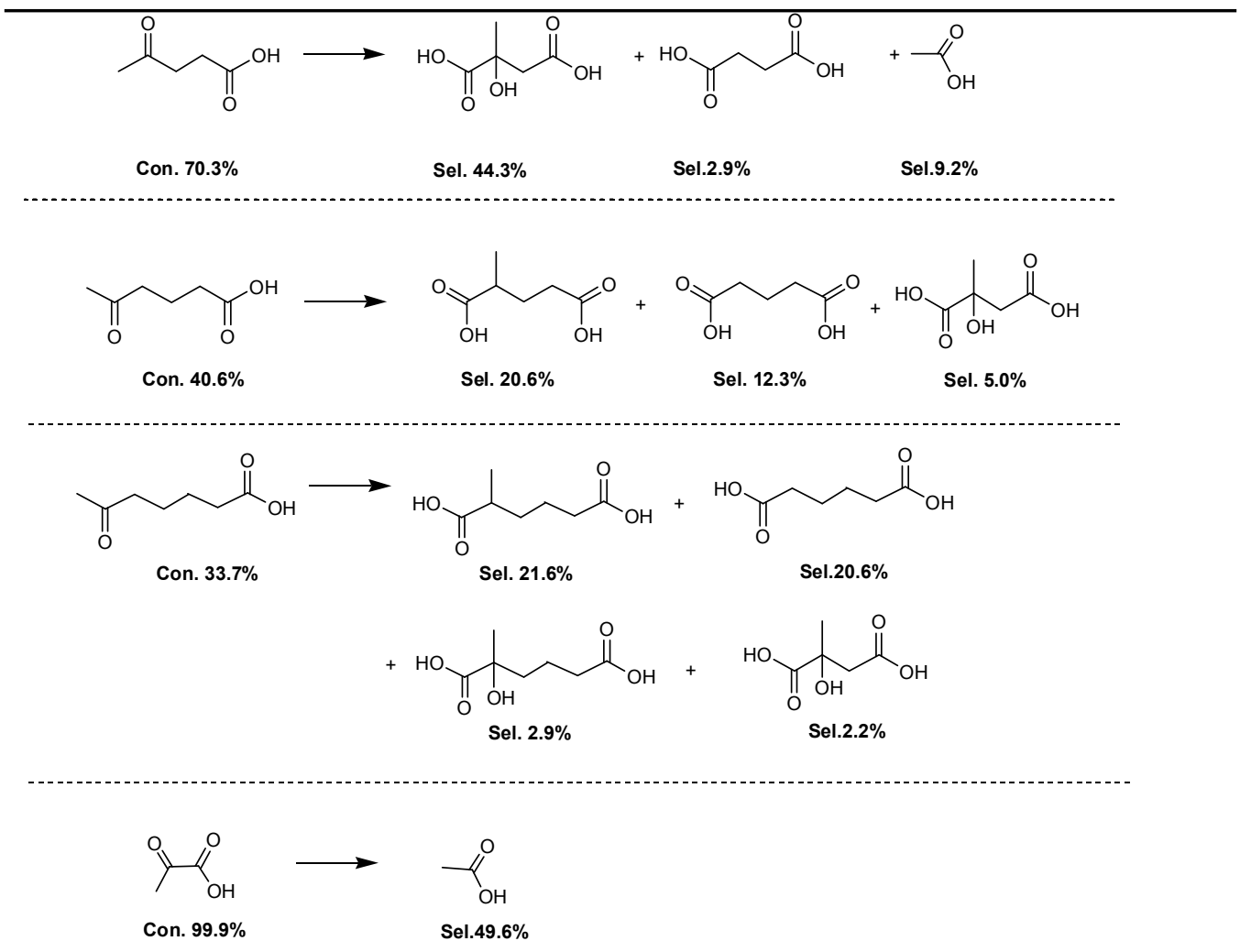

Reaction conditions: $1 \mathrm{NiOx} / \mathrm{CaO}(50 \mathrm{mg}), 3 \mathrm{~mL}$ of $0.05 \mathrm{~mol} / \mathrm{L}$ aqueous solution of feedstock, 1.0 $\mathrm{MPa} \mathrm{O}_{2}, 150{ }^{\circ} \mathrm{C}, 6 \mathrm{~h}$. 
Table S3. Results of aerobic oxidation of LA over various metal catalysts.

\begin{tabular}{cccccc}
\hline & & & \multicolumn{3}{c}{ Selectivity (\%) } \\
\cline { 4 - 6 } Entry & Catalysts & $\begin{array}{c}\text { Conversion } \\
(\%)\end{array}$ & $\mathrm{CA}$ & $\mathrm{SA}$ & $\mathrm{AA}$ \\
\hline 1 & $1 \mathrm{RuOx} / \mathrm{CaO}$ & 95.8 & 42.2 & 4.2 & 15.1 \\
2 & $1 \mathrm{PdO}_{\times} / \mathrm{CaO}$ & 99.4 & 45.3 & 0.5 & 10.3 \\
3 & $1 \mathrm{PtO}_{\times} / \mathrm{CaO}$ & 30.7 & 10.5 & 1.0 & 15.1 \\
4 & $1 \mathrm{AuO}_{\times} / \mathrm{CaO}$ & 31.4 & 34.1 & 2.3 & 29.1 \\
5 & $1 \mathrm{AgO}_{\times} / \mathrm{CaO}$ & 31.7 & 20.6 & 1.4 & 19.7 \\
6 & $1 \mathrm{NiO}_{\times} / \mathrm{CaO}$ & 70.3 & 44.3 & 2.9 & 9.2 \\
7 & $1 \mathrm{CuO}_{\times} / \mathrm{CaO}$ & 68.9 & 15.7 & 2.0 & 9.9 \\
\hline
\end{tabular}

Reaction conditions: $50 \mathrm{mg}$ of catalyst, $3 \mathrm{~mL}$ of $0.05 \mathrm{~mol} / \mathrm{L}$ levulinic acid aqueous solution, 1.0 $\mathrm{MPa} \mathrm{O}_{2}, 150^{\circ} \mathrm{C}, 6 \mathrm{~h}$. CA (2-hydroxy-2-methylsuccinic acid), SA (succinic acid), AA (acetic acid).

Table S4. Results of aerobic oxidation of LA over different catalysts.

\begin{tabular}{|c|c|c|c|c|c|}
\hline \multirow{2}{*}{ Entry } & \multirow{2}{*}{ Catalysts } & \multirow{2}{*}{$\begin{array}{l}\text { Conversion } \\
(\%)\end{array}$} & \multicolumn{3}{|c|}{ Selectivity (\%) } \\
\hline & & & $\mathrm{CA}$ & SA & AA \\
\hline 1 & 1RuOx/CaO 50 mg & 95.8 & 42.2 & 4.2 & 15.1 \\
\hline 2 & $\mathrm{CaCl}_{2}(0.05 \mathrm{~mol} / \mathrm{L})$ & 7.0 & 0 & 0 & 68.3 \\
\hline 3 & 1RuOx/HAP 50 mg & 5.5 & 0 & 0 & 0 \\
\hline $4^{[\mathrm{a}]}$ & $1 \mathrm{RuOx} / \mathrm{C}+\mathrm{CaCO}_{3}$ & 69.4 & 0 & 0 & 14.2 \\
\hline $5^{[a]}$ & $1 \mathrm{RuOx} / \mathrm{C}+\mathrm{CaO}$ & 92.0 & 78.3 & 3.0 & 4.3 \\
\hline 6 & $\begin{array}{c}\mathrm{CaCl}_{2}(0.05 \mathrm{~mol} / \mathrm{L})+2 \mathrm{NaOH}(0.10 \\
\mathrm{mol} / \mathrm{L})\end{array}$ & 51.5 & 20.2 & 2.3 & 25.5 \\
\hline 7 & $\mathrm{Ca}(\mathrm{OH})_{2} 50 \mathrm{mg}$ & 19.0 & 15.6 & 5.6 & 18.2 \\
\hline 8 & $\mathrm{Mg}(\mathrm{OH})_{2} 50 \mathrm{mg}$ & 0 & 0 & 0 & 0 \\
\hline 9 & $1 \mathrm{RuOx} / \mathrm{C}+\mathrm{NaOH}(50 \mathrm{mg}+50 \mathrm{mg})$ & 100 & 0 & 0 & 53.1 \\
\hline $10^{[a]}$ & $1 \mathrm{RuOx} / \mathrm{C}+\mathrm{CeO}_{2}$ & 63.3 & 0 & 1.8 & 18.9 \\
\hline $11^{[\mathrm{a}]}$ & $1 \mathrm{RuOx} / \mathrm{C}+\mathrm{La}_{2} \mathrm{O}_{3}$ & 70.0 & 0 & 0.8 & 10.8 \\
\hline
\end{tabular}

Reaction conditions: $3 \mathrm{~mL}$ of $0.05 \mathrm{~mol} / \mathrm{L}$ levulinic acid aqueous solution, $1.0 \mathrm{MPa} \mathrm{O}_{2}, 150{ }^{\circ} \mathrm{C}, 6$ $\mathrm{h}$; [a] $1 \mathrm{RuOx} / \mathrm{C} 50 \mathrm{mg}$, metal oxides or metal salts $50 \mathrm{mg}, 3 \mathrm{~mL}$ of $0.05 \mathrm{~mol} / \mathrm{L}$ levulinic acid aqueous solution, $0.5 \mathrm{MPa} \mathrm{O}_{2}, 110^{\circ} \mathrm{C}, 2 \mathrm{~h}$.

CA (2-hydroxy-2-methylsuccinic acid), SA (succinic acid), AA (acetic acid), HAP (hydroxyapatite). 
Table S5. Results of aerobic oxidation of LA with different solvents.

\begin{tabular}{cccccc}
\hline \multirow{2}{*}{ Entry } & Solvent & $\begin{array}{c}\text { Conversion } \\
(\%)\end{array}$ & \multicolumn{3}{c}{ Selectivity (\%) } \\
\cline { 4 - 6 } & & 90.8 & 94.7 & 0.8 & AA \\
\hline 1 & $\mathrm{H}_{2} \mathrm{O}$ & 61.8 & 0 & 0 & 0.5 \\
2 & Ethanol & 98.9 & 0 & 0 & 1.2 \\
3 & 1,4-Dioxane & CA & 0 & 34.9 \\
4 & $\begin{array}{c}\text { Tetrahydrofura } \\
\mathrm{n}\end{array}$ & 92.4 & 0 & 0 & 5.1 \\
\hline
\end{tabular}

Reaction conditions: $50 \mathrm{mg}$ of $1 \mathrm{RuOx} / \mathrm{C}$ catalyst, $50 \mathrm{mg}$ of $\mathrm{CaO}$ catalyst, $3 \mathrm{~mL}$ of $0.05 \mathrm{~mol} / \mathrm{L}$ levulinic acid aqueous solution, $0.5 \mathrm{MPa} \mathrm{O}_{2}, 90^{\circ} \mathrm{C}, 0.5 \mathrm{~h}$.

CA (2-hydroxy-2-methylsuccinic acid), SA (succinic acid), AA (acetic acid), HAP (hydroxyapatite).

Table S6. Results of LA oxidation with different additives.

\begin{tabular}{|c|c|c|c|c|c|c|}
\hline \multirow{2}{*}{ Entry } & \multirow{2}{*}{ Additives } & \multirow{2}{*}{ Catalysts } & \multirow{2}{*}{$\begin{array}{c}\text { Conversion } \\
(\%)\end{array}$} & \multicolumn{3}{|c|}{ Selectivity (\%) } \\
\hline & & & & CA & SA & AA \\
\hline 1 & None & $1 \mathrm{RuOx} / \mathrm{C}+\mathrm{CaO}$ & 90.8 & 94.7 & 0.8 & 0.5 \\
\hline 2 & $\begin{array}{l}\text { Ammonium } \\
\text { oxalate }\end{array}$ & $1 \mathrm{RuOx} / \mathrm{C}+\mathrm{CaO}$ & 85.8 & 88.2 & 1.0 & 4.5 \\
\hline 3 & Silver nitrate & $1 \mathrm{RuOx} / \mathrm{C}+\mathrm{CaO}$ & 78.2 & 66.2 & 0 & 8.6 \\
\hline 4 & Isopropanol & $1 \mathrm{RuOx} / \mathrm{C}+\mathrm{CaO}$ & 19.5 & 52.4 & 0 & 7.8 \\
\hline 5 & $\begin{array}{c}1,4- \\
\text { Benzoquinone }\end{array}$ & $1 \mathrm{RuOx} / \mathrm{C}+\mathrm{CaO}$ & 25.8 & 2.0 & 9.0 & 22.2 \\
\hline $6^{a}$ & $\mathrm{H}_{2} \mathrm{O}_{2}$ & $1 \mathrm{RuOx} / \mathrm{C}+\mathrm{CaO}$ & 15.2 & 70.3 & 0 & 12.1 \\
\hline $7^{a}$ & $\mathrm{H}_{2} \mathrm{O}_{2}$ & $1 \mathrm{RuOx} / \mathrm{C}+\mathrm{MgO}$ & 99.5 & 0 & 0 & 18.1 \\
\hline 8 & None & $1 \mathrm{RuOx} / \mathrm{C}+\mathrm{CaO}_{2}$ & 100 & 75.4 & 0 & 0 \\
\hline $9^{a}$ & None & $1 \mathrm{RuOx} / \mathrm{C}+\mathrm{CaO}_{2}$ & 7.9 & 36.7 & 0 & 0 \\
\hline $10^{\mathrm{a}}$ & None & $\mathrm{CaO}_{2}$ & 0.5 & 0 & 0 & 0 \\
\hline
\end{tabular}

Reaction conditions: $50 \mathrm{mg}$ of $1 \mathrm{RuOx} / \mathrm{C}$ catalyst, $50 \mathrm{mg}$ of $\mathrm{CaO} / \mathrm{MgO} / \mathrm{CaO}_{2}$ catalyst, $3 \mathrm{~mL}$ of $0.05 \mathrm{~mol} / \mathrm{L}$ levulinic acid aqueous solution, $0.5 \mathrm{MPa} \mathrm{O}_{2}, 90{ }^{\circ} \mathrm{C}, 0.5 \mathrm{~h}$; a All the conditions are the same to those for other experiments except no $\mathrm{O}_{2}$ being charged in the reactor.

CA (2-hydroxy-2-methylsuccinic acid), SA (succinic acid), AA (acetic acid). 
Table S7. The properties of CA modified PBS polymer.

\begin{tabular}{|c|c|c|c|c|}
\hline \multirow{2}{*}{ Entry } & \multirow{2}{*}{ Property } & \multicolumn{3}{|c|}{ PBS-CAs } \\
\hline & & PBS & $\mathrm{PBS}_{95} \mathrm{CA}_{5}$ & $\mathrm{PBS}_{90} \mathrm{CA}_{10}$ \\
\hline 1 & Feed ratio ${ }^{a}$ & SA:100; CA:0 & SA:95; CA:5 & SA:90,CA:10 \\
\hline 2 & Composition ratio ${ }^{b}$ & $\begin{array}{l}X_{B S}: 1.00 \\
X_{B C}: 0.00\end{array}$ & $\begin{array}{l}\mathrm{X}_{\mathrm{BS}}: 0.98 \\
\mathrm{X}_{\mathrm{BC}}: 0.02\end{array}$ & $\begin{array}{l}X_{B S}: 0.94 \\
X_{B C}: 0.06\end{array}$ \\
\hline 3 & $\mathrm{M}_{\mathrm{n}} / \mathrm{g} / \mathrm{mol}^{\mathrm{c}}$ & 30385 & 40365 & 28022 \\
\hline 4 & $\mathrm{M}_{\mathrm{w}} / \mathrm{g} / \mathrm{mol}^{\mathrm{c}}$ & 63858 & 71604 & 63063 \\
\hline 5 & $\theta^{\mathrm{c}}$ & 2.102 & 1.774 & 2.250 \\
\hline 6 & $\mathrm{~T}_{\mathrm{g}} /{ }^{\circ} \mathrm{C} d$ & l & l & l \\
\hline 7 & $\mathrm{~T}_{\mathrm{m}} /{ }^{\circ} \mathrm{C} \mathrm{d}$ & 115.5 & 112.2 & 106.8 \\
\hline 8 & $\mathrm{~T}_{\mathrm{C}} /{ }^{\circ} \mathrm{C} d$ & 70.2 & 64.7 & 60.9 \\
\hline 9 & $\begin{array}{l}\text { Moisture permeance factor / } \\
\left(\mathrm{g} \cdot \mathrm{cm} / \mathrm{cm}^{2} \cdot \mathrm{s} \cdot \mathrm{Pa}\right)^{\mathrm{e}}\end{array}$ & $3.058 \times 10^{-13}$ & $1.403 \times 10^{-13}$ & $4.824 \times 10^{-14}$ \\
\hline 10 & Tensile Strength / MPa ${ }^{f}$ & 26.0 & 31.0 & 36.5 \\
\hline 11 & $\begin{array}{l}\text { Tensile modulus of elasticity / } \\
\qquad \mathrm{MPa}^{\mathrm{f}}\end{array}$ & 446 & 275 & 208 \\
\hline 12 & Elongation at break $/ \%^{f}$ & $10 / 12^{g}$ & 208 & 690 \\
\hline
\end{tabular}

a Reaction condition: $180^{\circ} \mathrm{C}$ under atmospheric pressure for $6 \mathrm{~h}$, and then at $200^{\circ} \mathrm{C}$ under 10 $\mathrm{Pa}$ for $4 \mathrm{~h}$. ${ }^{\mathrm{b}}$ Calculated by ${ }^{1} \mathrm{HNMR} .{ }^{\mathrm{c}}$ Estimated by GPC. ${ }^{\mathrm{d}}$ Measured by Differential Scanning Calorimetry (DSC). e Measured by a permeation test system. ${ }^{f}$ Measured by Electronic Universal testing machine. ${ }^{9}$ Tachibana, Y.; Yamahata, M.; Kimura, S.; Kasuya, K. I. Synthesis, Physical Properties, and Biodegradability of Biobased Poly(Butylene Succinate- Co-Butylene Oxabicyclate). ACS Sustain. Chem. Eng. 2018, 6, 10806-10814. 